\title{
Sea-spray and marine biogenic seasonal contribution to snow composition at Terra Nova Bay, Antarctica
}

\author{
R. Udisti ${ }^{1 *}$ S. Begagli,${ }^{2}$ E. Castellano, ${ }^{2}$ R. Traversi,${ }^{2}$ S. Vermigli,${ }^{2}$ G. Pigcardi ${ }^{2}$ \\ ${ }^{1}$ Department of Chemistry, University of Calabria, I-87030 Arcavacata di Rende (Cosenza), Italy \\ ${ }^{2}$ Department of Public Health and Environmental Analytical Chemistry, University of Florence, Via G. Capponi 9, I-50121 Florence, Italy
}

\begin{abstract}
Primary and secondary marine aerosol contributions to snow composition in Terra Nova Bay, Antarctica, were evaluated by chemical analysis of surface and snow-pit samples. A seasonal pattern of marine inputs, very clear for secondary aerosol (mainly constituted by nssSO ${ }_{4}^{2-}$ and methanesulphonic acid (MSA) coming from phytoplanktonic activity) and less evident for sea spray $\left(\mathrm{Na}^{+}, \mathrm{Cl}^{-}, \mathrm{Mg}^{2+}\right)$, was shown by snowpit samples. Altitude and distance from the coast were found to be the main parameters affecting seasonal change in the composition of snow collected within about a $200 \mathrm{~km}$ radius of the Terra Nova Bay Italian base. Using $\mathrm{Na}^{+}$as a sea-spray indicator and MSA as a biogenic marker, fractionating aerosol effects (which are altitude-induced) as well as source contributions for $\mathrm{Cl}^{-}$and $\mathrm{nsSSO}_{4}{ }^{2-}$ were found. $\mathrm{A} \mathrm{nssSO}_{4}{ }^{2-} / \mathrm{MSA}$ ratio of $2.7(\mathrm{w} /$ $\mathrm{w}$ ), indicating their distribution from the common source dimethylsulphide, was calculated from analysis of fresh summer snow collected in horizontal and vertical transects in northern Victoria Land.
\end{abstract}

\section{INTRODUCTION}

Primary and secondary marine aerosols constitute the main contributions to the snow composition in coastal regions in Antarctica and may play an important role in the climate control of remote marine regions, as principal factors for cloud-condensation-nuclei formation (Charlson and others, 1987; Ayers and Gras, 1991). Antarctic coastal areas are directly exposed to marine air masses and are characterised by high annual snow accumulation. Chemical analysis of samples from snow pits and firn cores gives high-resolution records of the environmental and climatic history of the Southern Ocean (Wagenbach, 1996). Snow sampling at stations located in different geographic positions (altitude and distance from the sea) in the area surrounding Terra Nova Bay can give useful information about aerosol sources and transport processes (such as short- and long-range transport and fractionating effects). Variations in marine productivity can also be investigated by means of the seasonal pattern and the temporal and spatial distribution of some biogenic markers, such as non-sea-salt sulphate $\left(\mathrm{nssSO}_{4}{ }^{2-}\right)$ and methanesulphonic acid (MSA). Since these sulphur-cycle compounds are quite stable in glacial ice, the climatic conditions and phytoplanktonic-activity variations can also be evaluated for the past (Legrand and others, 1991; Saltzman, 1995).

$\mathrm{Cl}^{-}, \mathrm{Na}^{+}, \mathrm{Mg}^{2+}$ and, partially, $\mathrm{SO}_{4}{ }^{2-}$ are the typical components of primary marine aerosol (sea spray) which is the dominant component in snow collected in low-altitude coastal areas. When the distance from the sea and/or more importantly the altitude increases, the contribution of secondary

\footnotetext{
*Present address: Analytical Chemistry Section, University of Florence, Via G. Capponi 9, I-50121 Florence, Italy.
}

atmospheric aerosol becomes important. In unpolluted marine areas such as Antarctica, where the impact of other aerosol sources is low, the secondary marine aerosol is closely related to biologic processes. The main compound emitted by the oceanic phytoplanktonic activity is dimethylsulphide (DMS) which is oxidised in the atmosphere mainly to $\mathrm{H}_{2} \mathrm{SO}_{4}$ (determined as nss $\mathrm{SO}_{4}{ }^{2-}$ ) and MSA (Andreae and Raemdonck, 1983; Saltzman, 1995). MSA is exclusively produced by marine life (Savoie and Prospero, 1989; Legrand and others, 1991; Wagenbach, 1996), whereas $\mathrm{nssSO}_{4}{ }^{2-}$ has other potential sources such as volcanic, anthropogenic and crustal inputs (Legrand and Delmas, 1987; Shaw, 1988). In Antarctic coastal areas, however, the $\mathrm{nssSO}_{4}{ }^{2-}$ biogenic source is dominant, especially during summer (Legrand, 1995; Wagenbach, 1996; Udisti and others, 1998). The seasonal pattern of DMS emissions gives an analogous seasonal character to the MSA and $\mathrm{nssSO}_{4}{ }^{2-}$ content in aerosol and snow, with concentration maxima during the phytoplanktonic bloom periods and immediately thereafter (Prospero and others, 1991; Saltzman, 1995; Wagenbach, 1996; de Mora and others, 1997). Previous studies on the distribution of marine components in snow and firn samples collected in northern Victoria Land (Udisti and others, 1993, 1998; Piccardi and others, 1996a, b) revealed a sharp seasonal pattern for MSA and $\mathrm{nsSOO}_{4}{ }^{2-}$ (so their summer maxima can be used as reliable seasonal markers in firn-core dating; Udisti, 1996). There is a less evident seasonal trend for sea-spray components $\left(\mathrm{Cl}^{-}\right.$, $\mathrm{Na}^{+}, \mathrm{Mg}^{2+}$ ), but higher concentrations are found in winter snowfalls. A relevant influence of altitude on the chemical composition of snow and on aerosol fractionating effects was also observed.

The aim of this paper is to confirm and complete such observations with a large new dataset derived from chemical analysis of four snow pits sampled at different positions in coastal areas of Terra Nova Bay. A spatial evaluation of the 
summer marine contribution was also performed by analyzing fresh summer snow samples collected in vertical transects (stations located very close together but at different altitudes) and horizontal transects (stations at different distances from the coastline arranged along a sea-inland direction).

\section{SAMPLING AND ANALYTICAL METHODS}

\section{Sampling stations}

Terra Nova Bay is located between the Ross Sea and the Transantarctic Mountains, in a region affected by intense katabatic winds (Bromwich and Kurtz, 1984). Study of the seasonal pattern of snow components from snow-pit or firncore samples calls for undisturbed annual snow deposition. To avoid areas where wind effects on the snow cover (e.g. ablation or redistribution) can perturb the snow-layer deposition, a detailed analysis of satellite photos was performed (Stenni and others, unpublished). In this way, it was possible to choose stations where wind morphologies (e.g. sastrugi and snowdrift) were missing, so that an undisturbed snow deposition was highly probable.

Samples were obtained from four snow pits $(2.5-3.5 \mathrm{~m}$ deep) dug at stations located within about $200 \mathrm{~km}$ of the Terra Nova Bay Italian base, during the 1993-94 Italian Antarctic campaign.

During the Italian Antarctic campaigns from 1993-94 to 1996-97, about 100 samples of surface snow were collected in summer at different stations in the same area. In particular, surface snow from coast-inland transects was obtained along the Reeves-Priestley Névé and Rennick Névé. The surface snow was collected as soon as possible after deposition (maximum 2 days), so the samples can be considered as "fresh snow" samples, little affected by post-depositional processes.

\section{Sampling procedures and analytical methods}

All samples were collected using a sampling protocol to avoid contamination (Udisti and others, 1991, 1994; Piccardi and others 1994). The snow pits were hand-excavated by personnel wearing clean-room clothing. Pit walls were cleaned by removing a $5-10 \mathrm{~cm}$ snow layer with a stainless-steel scraper just before sampling. Pre-cleaned polypropylene vials (inside diameter $35 \mathrm{~mm}$ ) were inserted into the vertical snow walls, and after removal each sampling vial was sealed in a double polyethylene bag. The vials were kept frozen $\left(-20^{\circ} \mathrm{C}\right)$ until analysis (usually a few months after sampling).

Snow components were determined using an integrated system of three ion chromatographs (ICs) with conductivity detectors. The separation columns were Dionex AS12A $\left(\mathrm{Cl}^{-}\right.$, $\mathrm{Br}^{-}, \mathrm{NO}_{3}{ }^{-}, \mathrm{PO}_{4}{ }^{3-}$ and $\left.\mathrm{SO}_{4}{ }^{2-}\right)$, ASllA $\left(\mathrm{F}^{-}\right.$, acetate, propionate, formate, MSA and pyruvate) and Dionex $\mathrm{CSl} 2 \mathrm{~A}\left(\mathrm{Na}^{+}\right.$, $\mathrm{NH}_{4}{ }^{+}, \mathrm{K}^{+}, \mathrm{Mg}^{2+}$ and $\mathrm{Ca}^{2+}$ ), followed by electrochemical micro-membrane conductivity suppressors. All components were analyzed as soon as possible after melting (usually $30 \mathrm{~min}$ ). The samples were melted under a class 100 laminar hood and filtered on a $0.45 \mu \mathrm{m}$ Teflon membrane just before analysis. A $1 \mathrm{~mL}$ sample loop was sufficient to determine the lowest concentrations of the components without pre-concentration. Blank control procedures, sample treatment and IC methods are described in Udisti and others, (1991, 1994), Piccardi and others, (1994) and Udisti (1996).

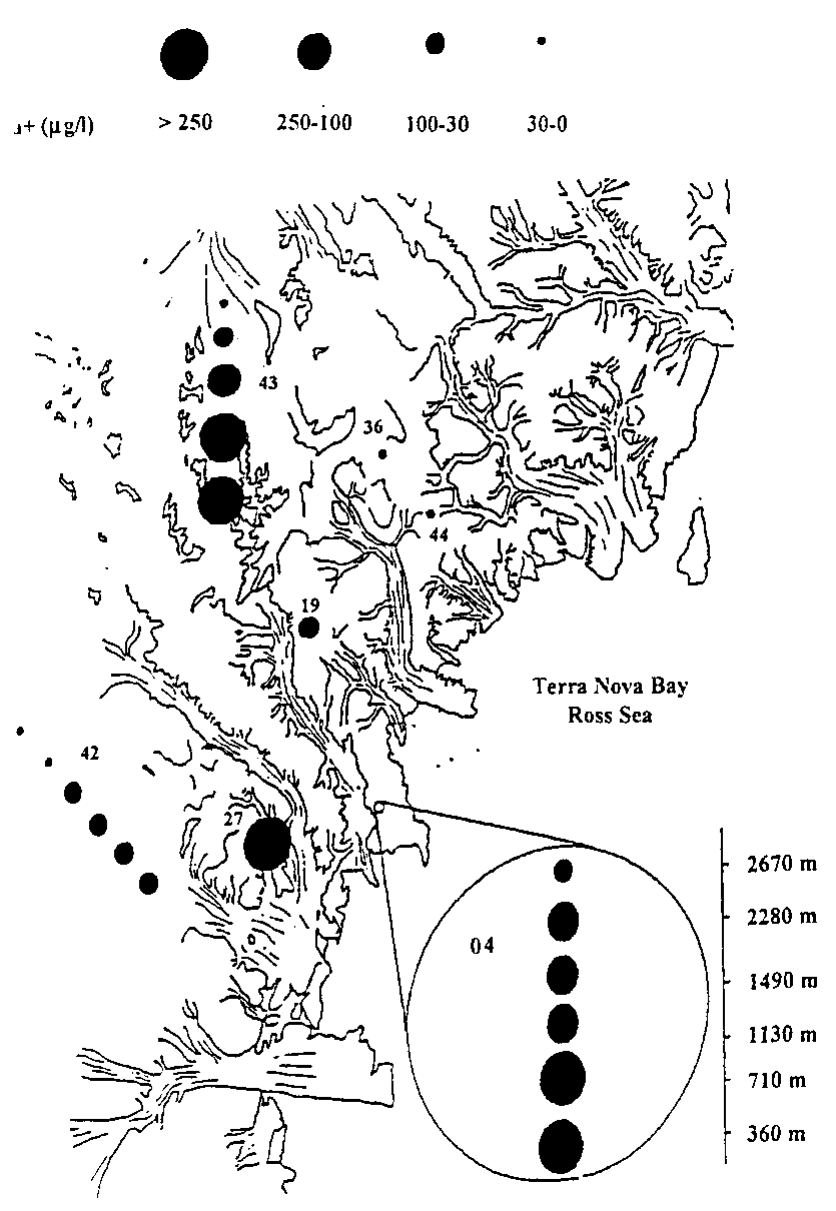

Fig. 1. Sampling area and distribution of $\mathrm{Na}^{+}$concentration. The $\mathrm{Na}^{+}$mean snow contents are grouped by concentration classes. Sampling stations:

04, Mount Melbourne. Surface snow: six sites between $74^{\circ} 32^{\prime} \mathrm{S}$, $164^{\circ} 46^{\prime} \mathrm{E}$ and $74^{\circ} 21^{\prime} \mathrm{S}, 164^{\circ} 41^{\prime} \mathrm{E}$ (360-2670 $\mathrm{m}$ a.s.l.).

19, Styx Glacier plateau. Snow pit: $73^{\circ} 52^{\prime}$ S, 634' E (1660 m a.s.l.).

27, McCarthy Ridge. Snow pit: $74^{\circ} 36^{\prime} \mathrm{S}, 163^{\circ} 03^{\prime} \mathrm{E}(870 \mathrm{~m}$ a.s.l.).

36, Hercules Néve. Snow pit: $73^{\circ} 06^{\prime} \mathrm{S}, 165^{\circ} 28^{\prime}$ E (2960 m a.s.l.).

44, Pilot Glacier. Snow pit: $73^{\circ} 16^{\prime}$ S, $165^{\circ} 31^{\prime}$ E (2100 m a.s.l.).

Transect 42, Reeves-Priestley Plateau. Surface snow: eight sites spaced $10-20 \mathrm{~km}$ apart from $74^{\circ} 29^{\prime} \mathrm{S}, 161^{\circ} 00^{\prime} \mathrm{E}$ (1540 m a.s.l.) to $73^{\circ} 37^{\prime} \mathrm{S}, 157^{\circ} 54^{\prime} \mathrm{E}$ (2320 m a.s.l.).

Transect 43, Rennick Glacier plateau. Surface snow: nine sites spaced 10-20 km apart from $73^{\circ} 20^{\prime} \mathrm{S}, 162^{\circ} 30^{\prime} \mathrm{E}$ (2210 m a.s.l.) to $72^{\circ} 20^{\prime} \mathrm{S}, 162^{\circ} 26^{\prime} \mathrm{E}$ (1350 m a.s.l.). The elevation decreases away from the sea.

Not all the stations are visible, because some sampling points are obscured by the dark patches indicating the $\mathrm{Na}^{+}$concentrations.

For each sample, the $\mathrm{nssSO}_{4}{ }^{2-}$ concentration was calculated (Maupetit and Delmas, 1992) by

$\left[\mathrm{nsSSO}_{4}{ }^{2-}\right]=\left[\mathrm{SO}_{4}{ }^{2-}\right]_{\mathrm{tot}}-0.253\left[\mathrm{Na}^{+}\right]$or $-0.139\left[\mathrm{Cl}^{-}\right](\mathrm{w} / \mathrm{V})$.

Previous $\mathrm{nssSO}_{4}{ }^{2-}$ measurements on samples collected in the same region indicated that $\mathrm{Na}^{+}$is the best sea-spray marker. In the lowest-elevation station (station 27, McCarthy Ridge, 870 ma.s.l.) some negative $\mathrm{nssSO}_{4}{ }^{2-}$ 

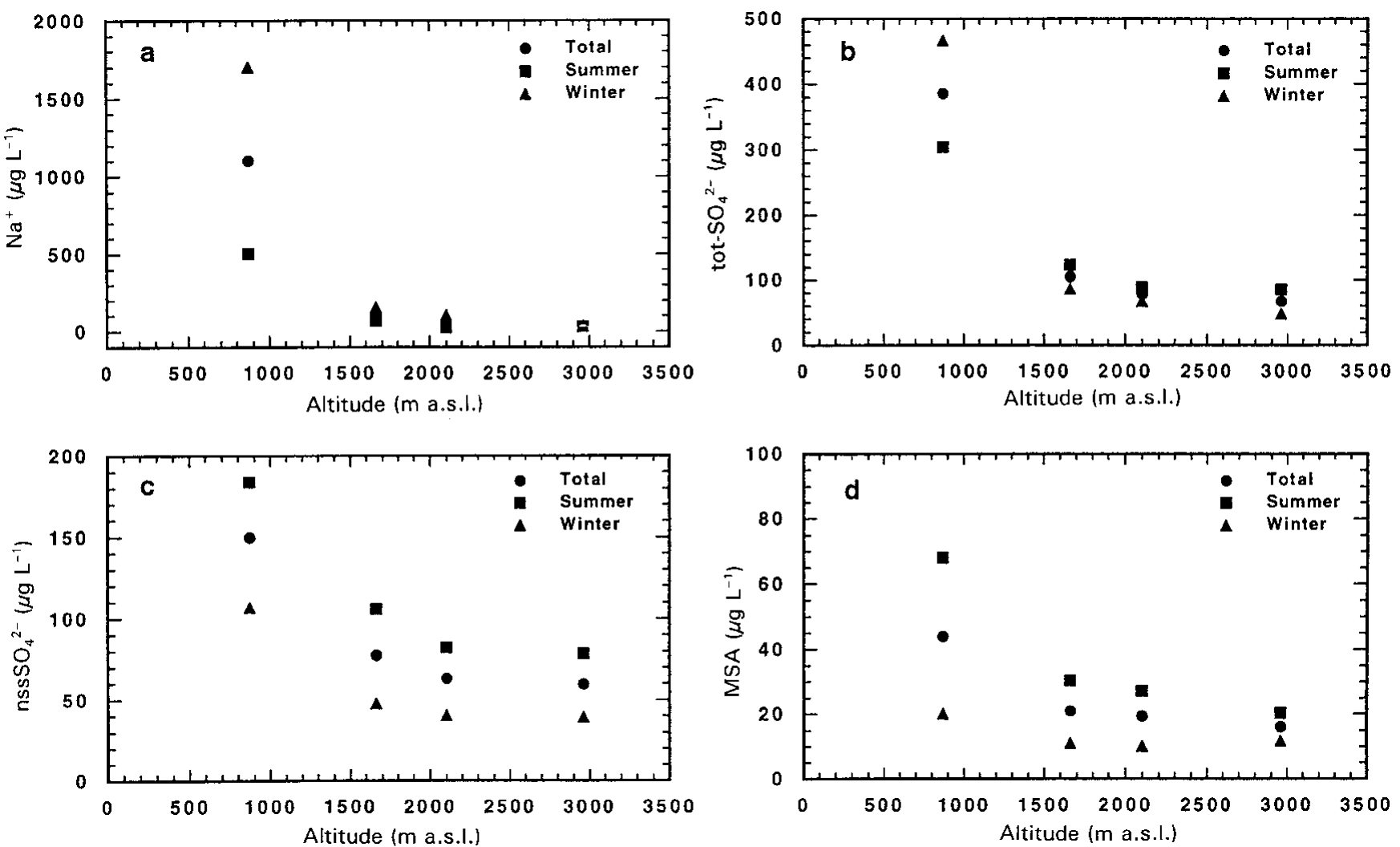

Fig. 2. Seasonal mean trends of $\mathrm{Na}^{+}$(a), total sulphate (b), non-sea-salt sulphate (c) and MSA (d) as functions of altitude in snow-pit samples collected at stations $27(870 \mathrm{~m}), 19(1660 \mathrm{~m}), 44(2100 \mathrm{~m})$ and $36(2960 \mathrm{~m})$.

values were found in winter samples, when the biogenic contribution was very low. For a reliable comparison of all snow-pit data, only positive nssSO $_{4}{ }^{2-}$ values were used for the statistical treatments. A detailed discussion of the $\mathrm{nssSO}_{4}{ }^{2-}$ calculation can be found in Udisti (1996).

The snow-pit dating was performed using a multiparametric method based on normalisation of the concentration/depth profiles of $\mathrm{H}_{2} \mathrm{O}_{2}, \mathrm{nssSO}_{4}{ }^{2-}$ and MSA (Udisti, 1996). The dating results are reported in Piccardi and others (1995). The normalised profiles of the three seasonal indicators gave a new, more reliable seasonal profile (designated the "normalised sum"), with a sinusoidal pattern, where the maximum values are related to summer samples and the minimum values to winter samples. Summer samples are those with a normalised sum value higher than half of the relative annual peak height, and winter samples those with lower normalised sum values.

\section{RESULTS AND DISGUSSION}

Sea-salt concentrations in Antarctic snow show the largest spatial and temporal variations, compared to other source components. In aerosol measurements, the mean concentrations range from $0.062 \mu \mathrm{g} \mathrm{m}^{-3}$ at the South Pole (Tuncel and others, 1989) to $3.2 \mu \mathrm{g} \mathrm{m}^{-3}$ on the Antarctic Peninsula (Palmer station; Wagenbach, 1996). Coastal sites influenced by katabatic winds, which are able to blow away the marine air masses from the coastal areas, show an intermediate sea-salt aerosol content ( $0.27 \mu \mathrm{g} \mathrm{m}^{-3}$ at Mawson; Wagenbach, 1996).

Allen and others (1985), analyzing two ice cores collected at two stations located in northern Victoria Land (Evans Névé and Morozumi Range), found the following respective median values for some of the compounds discussed here: chloride 147 and $163 \mu \mathrm{g} \mathrm{L}^{-1}$; sodium 81.6 and $87.6 \mu \mathrm{g} \mathrm{L}^{-1}$; sulphate 68.2 and $73 \mu \mathrm{g} \mathrm{L}^{-1}$.

Figure 1 shows the firn-core and surface-snow sampling stations. For each station, the mean concentration of $\mathrm{Na}^{+}$ (considered as a specific sea-spray marker) is reported (proportional to the symbol size). The importance of location in examining the contribution of sea spray to the snow composition is shown by the fact that the highest mean $\mathrm{Na}^{+}$contents are at the lower-altitude coastal stations (Fig. 1). In particular, the importance of distance from the sea and altitude is highlighted by the Reeves-Priestley (horizontal) and Melbourne (vertical) transects, respectively. For the Reeves-Priestley transects, the sampling sites were spaced about $10-20 \mathrm{~km}$ apart and located at high altitudes (1540$2320 \mathrm{~m}$ a.s.l.). A progressive decrease of the $\mathrm{Na}^{+}$mean concentration is evident for the low absolute values. The Melbourne transect gives very useful information concerning the altitude effect. In fact, the samples were collected at closely spaced stations but at very different altitudes. The $\mathrm{Na}^{+}$decrease is very sharp for the first $1000 \mathrm{~m}$. At higher altitudes, the decreasing trend is less evident.

The Rennick transect shows an apparent anomaly. The $\mathrm{Na}^{+}$concentration decreases as the altitude decreases. This glacier is located behind the Transantarctic Mountains, and therefore the altitude decreases in the inland direction. The marine air masses coming from the Ross Sea and up Campbell Glacier must rise over $2500 \mathrm{~m}$ before they reach the Rennick Glacier plateau, and so the sea-spray aerosol content is deposited preferentially at the highest Rennick site (first site at $2210 \mathrm{~m}$ a.s.l.; see also Fig. 1 caption).

Figure 2 shows the altitude effect and the seasonal pattern of the primary $\left(\mathrm{Na}^{+}\right.$; Fig. $\left.2 \mathrm{a}\right)$ and secondary $\left(\mathrm{nssSO}_{4}{ }^{2-}\right.$ 

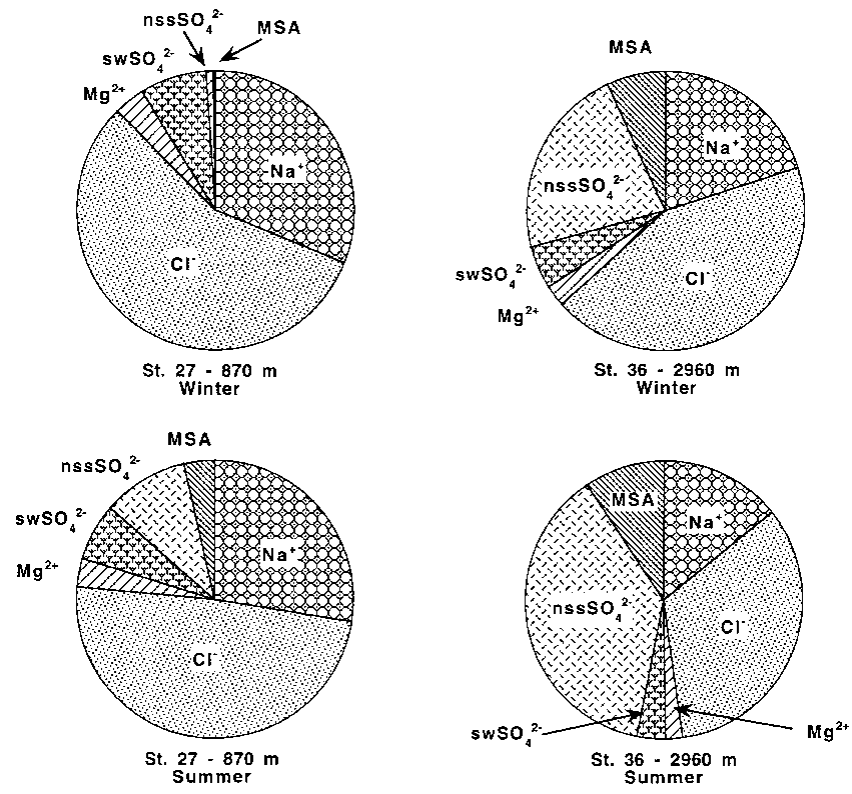

Fig. 3. Winter and summer percentage contributions of primary $\left(\mathrm{Na}^{+}, \mathrm{Cl}, \mathrm{Mg}^{2+}\right.$, sea-water sulphate) and secondary (nonsea-water sulphate, MSA) marine inputs at the lowest (station 27, McCarthy Ridge) and highest ( station 36, Hercules Névé) snow-pit stations.

and MSA; Fig. 2c and d) marine aerosol in the four snow pits. The $\mathrm{Na}^{+}$concentration is high in the lower station, with a maximum mean value in winter, but decreases quickly in the first altitude step $(870-1660 \mathrm{~m})$. Above $1500 \mathrm{~m}$, the concentrations are very low and the seasonal differences less evident. At Hercules Névé station (2960 m a.s.l.), a seasonal trend is lacking. A similar pattern is shown by $\mathrm{Cl}^{-}$and $\mathrm{Mg}^{2+}$. On the other hand, $\mathrm{nssSO}_{4}{ }^{2-}$ concentrations are higher in summer at all stations, and the tendency to decrease as a function of altitude is more gradual. For altitudes above $2000 \mathrm{~m}$, the concentration approaches $60 \mu \mathrm{g} \mathrm{L}^{-1}$. This pattern is confirmed by the MSA concentration trend (Fig. 2d), but a lower seasonal variation is observed for the highest station, where summer and winter mean concentration values are quite similar, ranging from 10 to $20 \mu \mathrm{g} \mathrm{L}^{-1}$. Figure $2 \mathrm{~b}$ shows the behaviour of total sulphate. At the lowest station, sulphate follows the same trend as $\mathrm{Na}^{+}$, with high winter values. From 870 to $1660 \mathrm{~m}$, the concentration drops quickly, while the decrease in percentage is lower than for $\mathrm{Na}^{+}$. From 1660 to $2960 \mathrm{~m}$, the sulphate shows an opposite seasonal pattern, with maxima in summer. As for $\mathrm{nssSO}_{4}{ }^{2-}$, a seasonal distribution is also revealed by tot $\mathrm{SO}_{4}{ }^{2-}$ for the highest station. This shows that the $\mathrm{SO}_{4}{ }^{2-}$ contribution from sea spray is partially counterbalanced by the presence of biogenic sources, which gain importance as altitude increases.

The different contributions of primary and secondary marine aerosols as a function of altitude and seasonality are shown in Figure 3. In winter, at the lowest station (station 27), the sea-spray content $\left(\mathrm{Na}^{+}, \mathrm{Cl}^{-}, \mathrm{Mg}^{2+}\right.$ and $\mathrm{swSO}_{4}{ }^{2-}$ ) is more than $95 \%$ of the total marine contribution. On the other hand, in summer at the highest station (station 36) the secondary marine aerosol $\left(\mathrm{nssSO}_{4}{ }^{2-}\right.$ and MSA) constitutes about $50 \%$ of the marine input. These data are in agreement with long-term aerosol observations at Neumayer station (Wagenbach, 1996). In winter, 90\% of the dry aerosol mass concentration consists of sea salt, and the other $10 \%$ consists of $\mathrm{nssSO}_{4}{ }^{2-}$ and $\mathrm{NO}_{3}{ }^{-}$in a ratio of approximately $1: 1$. In summer, the sea-spray content is reduced to $50 \%$, while the marine biogenic compounds (nssSO ${ }_{4}^{2-}$ and MSA) constitute the remaining $50 \%$.

The seasonal variations of the sea-salt load are relatively weak (at least for stations above $1000 \mathrm{~m}$ a.s.l.) and are not in phase with the annual sea-ice cycle. Minimum sea-spray values in aerosol and snow samples are found in summer when the sea surface is open, and maximum concentrations are measured in autumn and spring when the sea-ice extent is usually greater. Sudden high concentration peaks of sea spray are evident in winter, with values 10-100 times higher than mean seasonal values, especially at the lowest station (Piccardi and others, 1994). A similar pattern is shown by aerosol measurements from other coastal stations (Mawson, Neumayer and Dumont D'Urville; Wagenbach, 1996 and references therein). The sea-spray source areas and the transport pathways of such highly enriched sea-spray aerosol are not well known. Heavy salt storms, which are more probable in winter, could be the primary cause, although local sea-ice conditions must also be considered. A winter polynya in Terra Nova Bay is well documented (Bromwich and Kurtz, 1984) and a combination between such a polynya
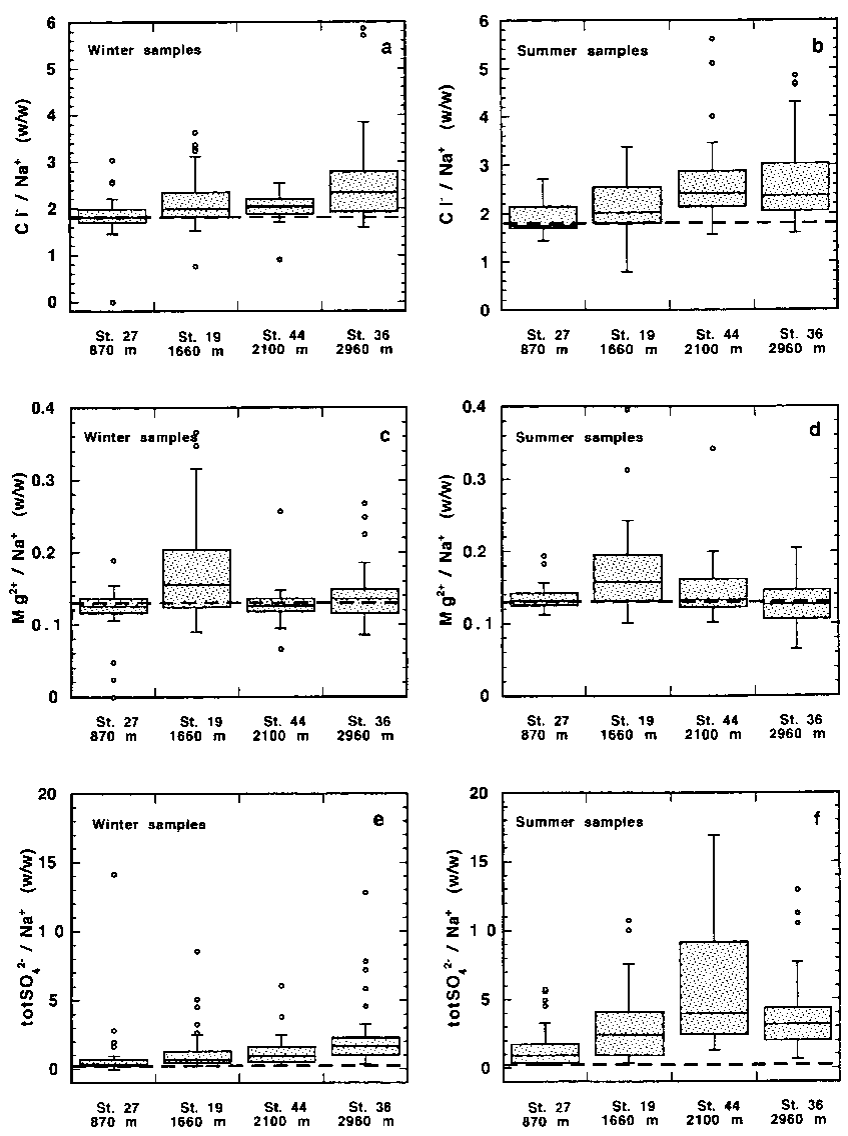

Fig. 4. Distribution plots of $\mathrm{Cl} / \mathrm{Na}^{+}, \mathrm{Mg}^{2+} / \mathrm{Na}^{+}$and tot$\mathrm{SO}_{4}{ }^{2-} / \mathrm{Na}^{+}$ratios in winter $(a, c, e)$ and summer $(b, d, f)$, for the four snow-pit stations. Each box contains $50 \%$ of the data, with the median value displayed as a line. The top and bottom of the box mark the limits of $\pm 25 \%$ of the variable population (25th and 75th percentiles). The lines extending from the top and bottom of each box mark the minimum and maximum values that fall within an acceptable range (1.5 times the box width). Any value outside this range (outlier) is shown as an individual point. The dashed lines indicate the sea-water composition. 

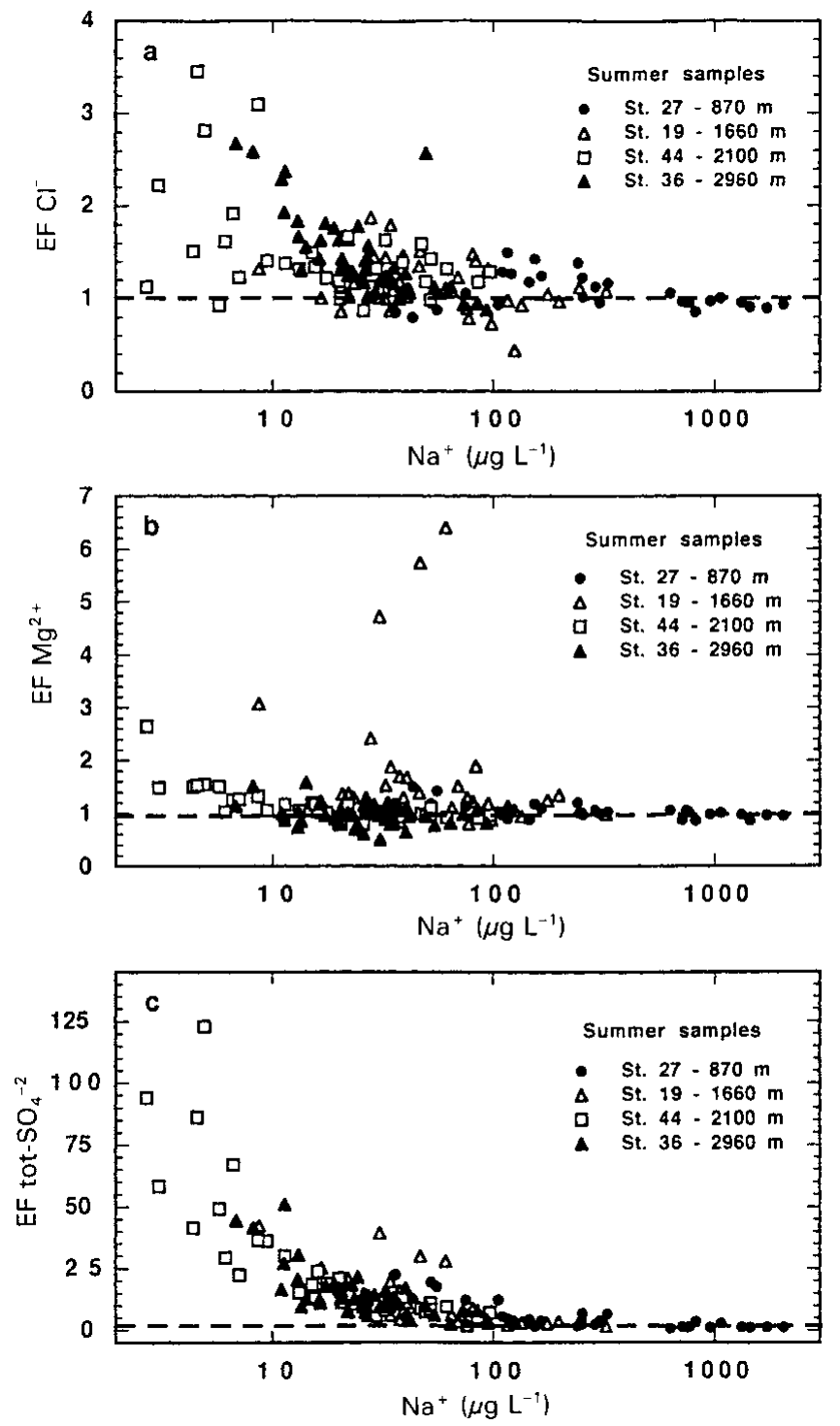

Fig. 5. Enrichment factors of $\mathrm{Cl}(\mathrm{a}), \mathrm{Mg}^{2+}$ (b) and tot $\mathrm{SO}_{4}{ }^{2-}$ (c) (by using $\mathrm{Na}^{+}$as sea-spray marker) in summer samples for the four snow-pit stations plotted os $\mathrm{Na}^{+}$concentration. The dashed lines indicate the sea-water composition.

and a heavy storm with marine winds seems to be a reliable explanation for sea-spray winter maxima.

By using $\mathrm{Na}^{+}$concentrations as a sea-spray marker, it is possible to demonstrate the fractionation phenomena related to the increase in altitude. Figure $4 \mathrm{a}-\mathrm{f}$ show the distribution diagrams (box plots) of the $\mathrm{Cl}^{-} / \mathrm{Na}^{+}, \mathrm{Mg}^{2+} / \mathrm{Na}^{+}$ and tot $\mathrm{SO}_{4}{ }^{2-} / \mathrm{Na}^{+}$concentration ratios for the four snow pits sampled as a function of seasonality and altitude. Each box indicates the concentration range of $50 \%$ of the samples, and its height is correlated to the variability in the data. The lines in the boxes indicate the median values, and the dashed lines represent the sea-water ratios. In winter, the data variability is generally low and the median ratio values are similar to those of sea water. In summer on the other hand, only the $\mathrm{Mg}^{2+} / \mathrm{Na}^{+}$ratio remains similar to the sea-water composition (except at station 19, where a $\mathrm{Mg}^{2+}$ crustal contribution occurs; Piccardi and others, 1996a), while $\mathrm{Cl}^{-} / \mathrm{Na}^{+}$and, above all, tot $\mathrm{SO}_{4}{ }^{2-} / \mathrm{Na}^{+}$ratios are higher. This difference, relative to the sea-water composition, increases with altitude. For the tot $\mathrm{SO}_{4}{ }^{2-} / \mathrm{Na}^{+}$trend, the explanation is clear. The biogenic contribution, which is very important in summer, increases the ratio with re- spect to the sea-water content. For $\mathrm{Cl}^{-}$, fractionation of the aerosol during transport must be considered. So too must other non-sea-salt $\mathrm{Cl}^{-}$sources such as volcanic inputs, longrange $\mathrm{HCl}$ transport or $\mathrm{HCl}$ formation from a reaction between $\mathrm{NaCl}$ and $\mathrm{H}_{2} \mathrm{SO}_{4}$ in aerosol. To illustrate the $\mathrm{Na}^{+}$ effect, the enrichment factors for $\mathrm{Cl}^{-}, \mathrm{Mg}^{2+}$ and tot $\mathrm{SO}_{4}{ }^{2-}$ in summer samples are reported as a function of $\mathrm{Na}^{+}$concentration (Fig. $5 \mathrm{a}-\mathrm{c}$ ). The enrichment factor (EF) for compound $\mathrm{X}$ is calculated as:

$$
\mathrm{EF}=([\mathrm{X}] /[\mathrm{Na}])_{\text {snow }} /([\mathrm{X}] /[\mathrm{Na}])_{\text {sea water }}
$$

The $\mathrm{Na}^{+}$scale is logarithmic to point out the trend at the lowest $\mathrm{Na}^{+}$concentrations. A general increase in $\mathrm{Cl}^{-}$and tot $\mathrm{SO}_{4}{ }^{2-} \mathrm{EF}$ when the $\mathrm{Na}^{+}$concentration decreases is evident in all snow-pit stations. The increase in the $\mathrm{Cl}^{-} / \mathrm{Na}^{+}$ ratio, which is more evident in summer, may be related to seasonality (aerosol transport processes or seasonal pattern of other $\mathrm{Cl}^{-}$sources). On the other hand, the non-sea-salt contribution to the $\mathrm{Cl}^{-}$concentration could be quite constant all year round, but with the $\mathrm{Cl}^{-}$excess (with respect to the sea-water $\mathrm{Cl}^{-} / \mathrm{Na}^{+}$ratio) becoming evident only in summer when the sea-spray contribution is lower (low values of $\mathrm{Na}^{+}$). This second hypothesis is supported by the experimental observation that at the highest elevation, where the $\mathrm{Na}^{+}$content is always low (low contribution of sea spray), the $\mathrm{Cl}^{-}$enrichments are similar both in summer and in winter (Fig. 4a and b).

Figure $5 \mathrm{c}$ shows high sulphate enrichment with respect to the sea-water composition in all stations. Enrichment factors in the range 20-100 are found for $\mathrm{Na}^{+}$concentrations of $<10 \mu \mathrm{g} \mathrm{L}^{-1}$. For this component both the above hypotheses are true. The seasonality of the biogenic source of $\mathrm{nssSO}_{4}{ }^{2-}$ is clear, and its contribution to the total sulphate budget is even more evident when the sea-spray contribution is low, as it is in summer and at high-altitude stations.

Just as $\mathrm{Na}^{+}$was used for the evaluation of the sea-spray contribution, MSA can be used as a biogenic marker to explain the biogenic contribution of $\mathrm{nssSO}_{4}{ }^{2-}$ and to estimate the distribution processes between MSA and $\mathrm{H}_{2} \mathrm{SO}_{4}$ coming from DMS. Such evaluations have to be performed on summer samples, where the biogenic contribution is higher, and in the absence of any post-depositional processes which can change the snow composition. For this reason, samples of fresh summer snow were collected just after deposition within about a $200 \mathrm{~km}$ radius of the Terra Nova Bay Italian base. Figure $6 \mathrm{a}$ shows the relationship between $\mathrm{nssSO}_{4}{ }^{2-}$ and MSA. There is a good correlation $(R=0.82, n=95)$, with a slope (indicating the summer mean $\mathrm{nsSSO}_{4}{ }^{2-} / \mathrm{MSA}$ ratio) of 2.7. Figure $6 \mathrm{~b}$ shows the trend of the $\mathrm{nsSSO}_{4}{ }^{2-} / \mathrm{MSA}$ $(\mathrm{w} / \mathrm{w})$ ratio as a function of MSA concentration. In the same figure, the dashed line indicates the ratio value of 2.7. For MSA concentrations as high as $50 \mu \mathrm{g} \mathrm{L}^{-1}$, the $\mathrm{nssSO}_{4}{ }^{2-}$ / MSA clearly tends to a value very near to 2.7. When the MSA concentration decreases, the ratio progressively increases to values even higher than 20. The highest values of the $\mathrm{nss}_{\mathrm{SO}}{ }_{4}{ }^{2-} / \mathrm{MSA}$ ratio are mainly obtained at the highest-elevation stations. The trend in the $\mathrm{nsSSO}_{4}{ }^{2-} / \mathrm{MSA}$ ratio could be explained by one or more of the following:

(1) the relative importance of non-DMS sources to the $\mathrm{nsSSO}_{4}{ }^{2-}$ budget;

(2) the effect of aerosol fractionation during transport progressively enriching $\mathrm{nssSO}_{4}{ }^{2-}$ (with respect to the original $\mathrm{nsSOO}_{4}{ }^{2-} / \mathrm{MSA}$ ratio from DMS), as distance from 

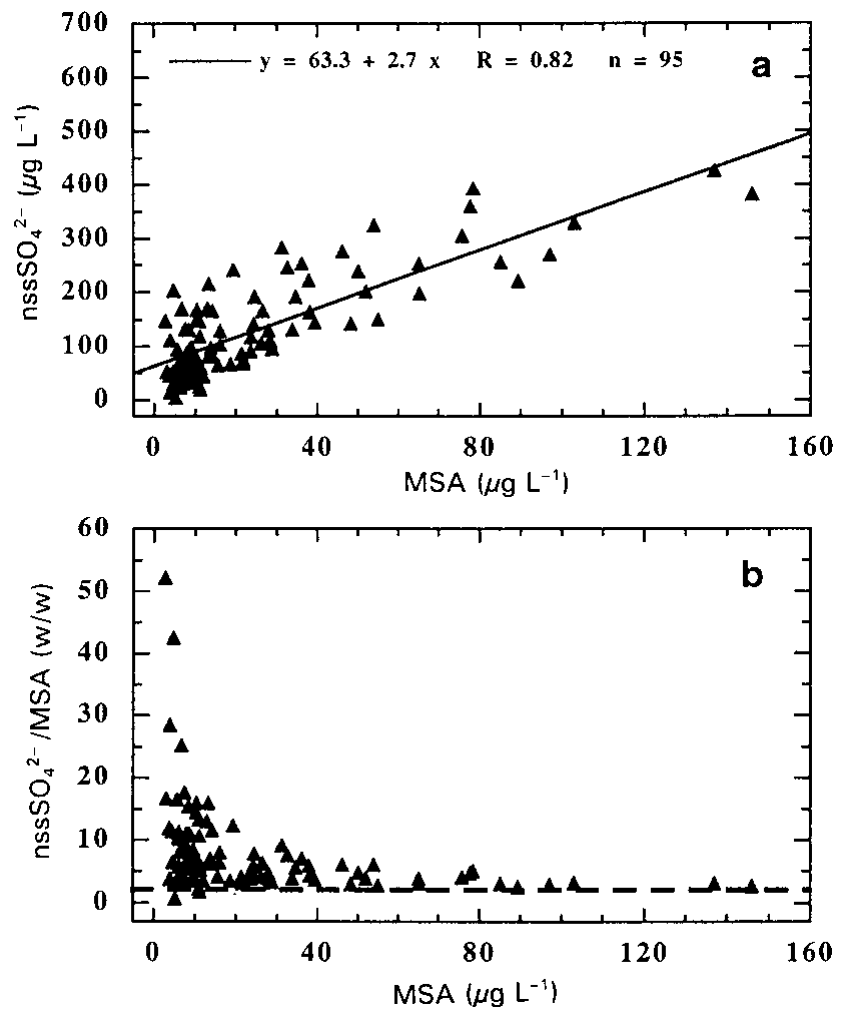

Fig. 6. (a) nss $\mathrm{SO}_{4}{ }^{2-}$ as a function of MSA concentration for summer fresh samples collected within a $200 \mathrm{~km}$ radius of the Terra Nova Bay Italian base, and (b) nss $\mathrm{SO}_{4}{ }^{2-} / \mathrm{MSA}$ ratio as a function of MSA concentration for the same samples.

the sea and altitude increase;

(3) the contribution of marine air masses coming from lower latitudes (long-range aerosol transport) with an original nss $\mathrm{SO}_{4}{ }^{2-} / \mathrm{MSA}$ ratio higher than that obtained in the Antarctic oceans.

In fact, the $\mathrm{nsSSO}_{4}{ }^{2-} / \mathrm{MSA}$ ratio is strongly affected by latitude (Bates and others, 1992). At medium latitudes, the $\mathrm{nsSSO}_{4}{ }^{2-}$ MSA aerosol ratio can reach values more than ten times greater than those found in the polar regions (Berresheim, 1987; Saltzman, 1995). Moreover, the positive relationship between altitude and $\mathrm{nssSO}_{4}{ }^{2-} / \mathrm{MSA}$ ratio leads us to believe that the different sizes of aerosol particles can play a relevant role. For example, the smaller aerosol particles are more involved in long-range aerosol transport from Southern mid-latitudes to Antarctic coastal areas (Wagenbach, 1996).

A simpler explanation for the pattern of the $\mathrm{nssO}_{4}{ }^{2-}$ / MSA ratio as a function of the MSA concentration is obtained by considering a quite constant and globally distributed background $\mathrm{nssSO}_{4}{ }^{2-}$ contribution (volcanic, crustal and/or from long-range transport), with a superimposed biogenic contribution. When the biogenic source decreases (due to seasonal variation and/or altitude effects) the background $\mathrm{nssSO}_{4}{ }^{2-}$ concentration becomes more important, leading to a progressive increase in the $\mathrm{nssSO}_{4}{ }^{2-} / \mathrm{MSA}$ ratio.

\section{CONGLUSIONS}

The principal contributions to snow composition in northern Victoria Land are primary and secondary marine aerosol, and their relative importance varies as a function of season and position. This phenomenon can be demonstrated by observing the spatial and seasonal distribution of some compo- nents chosen as primary $\left(\mathrm{Na}^{+}, \mathrm{Mg}^{2+}, \mathrm{Cl}^{-}\right.$and tot $\left.\mathrm{SO}_{4}{ }^{2-}\right)$ and secondary (MSA and nssSO ${ }_{4}{ }^{2-}$ ) aerosol markers.

Altitude and distance from the sea are fundamental parameters in understanding the distribution processes of components coming from sea spray as well as from marine biogenic activity. When altitude and distance from the sea increase, fractionation phenomena related to the aerosol particle size occur. In particular, we found larger $\mathrm{Cl}^{-}$enrichments in summer samples than in winter samples, but this seasonal difference disappears in the highest stations. This proves the existence of other $\mathrm{Cl}^{-}$sources, evident only when the $\mathrm{Na}^{+}$concentration is lower (summer precipitation and/or high altitudes, where the relatively large sea-spray particles arrive with difficulty).

For total sulphate, the enrichment with respect to sea-water composition prevalently found in summer is mainly due to the seasonality of the biogenic source $\left(\mathrm{nssSO}_{4}{ }^{2-}\right.$ from DMS).

Evaluation of the biogenic contribution to the $\mathrm{nssSO}_{4}{ }^{2-}$ budget as a function of seasonality is difficult because of the contributions of other sulphate sources such as volcanic and crustal inputs.

A nssSO ${ }_{4}{ }^{2-} / \mathrm{MSA}$ ratio of 2.7 was calculated from fresh summer snow samples, and this value could be representative for their distribution from DMS in northern Victoria Land coastal areas. The $\mathrm{nsSOO}_{4}{ }^{2-} / \mathrm{MSA}$ ratio plotted vs MSA concentration, used as a specific biogenic marker, confirms this ratio for high MSA concentrations, but shows a progressive increase when the MSA concentration decreases. Several factors may explain this increase, e.g. the contribution of a background $\mathrm{nssSO}_{4}{ }^{2-}$ value from nonDMS sources (volcanic and crustal), the effect of aerosol fractionation during transport (related to altitude and distance from the sea) or the contribution of marine air masses coming from mid-latitudes with different $\mathrm{nsSSO}_{4}{ }^{2-} / \mathrm{MSA}$ ratios from DMS.

\section{ACKNOWLEDGEMENTS}

This research was carried out in the framework of the Programma Nazionale di Ricerche in Antartide. It was financially supported by Ente per le Nuove Tecnologie, l'Energia e l'Ambiente.

\section{REFERENGES}

Allen, B., III, P. A. Mayewski, W. B. Lyons and M. J. Spencer. 1985. Glaciochemical studies and estimated net mass balances for Rennick Glacier area, Antarctica. Ann. Glaciol., 7, 1-6.

Andreae, M. O. and H. Raemdonck. 1983. Dimethyl sulphide in the surface ocean and the marine atmosphere: a global view. Science, 221 (4612), 744-747.

Ayers, G. P. and J. L. Gras. 1991. Seasonal relationship between cloud condensation nuclei and aerosol methanesulphonate in marine air. Nature, 353 (6347), 834-835.

Bates, T. S., J. A. Calhoun and P. K. Quinn. 1992. Variations in the methanesulfonate to sulfate molar ratio in submicrometer marine aerosol particles over the south Pacific Ocean. F. Geophys. Res., 97(D9), 9859-9865.

Berresheim, H. 1987. Biogenic sulfur emissions from the subantarctic and Antarctic oceans. 7. Geophys. Res., 92(D11), 13,245-13,262.

Bromwich, D. H. and D. D. Kurtz. 1984. Katabatic wind forcing of the Terra Nova Bay polynya. 7. Geophys. Res., 89(C3), 3561-3572.

Charlson, R. J., J. E. Lovelock, M. O. Andreae and S. G. Warren. 1987. Oceanic phytoplankton, atmospheric sulphur, cloud albedo and climate. Nature, 326(6114), 655-661.

de Mora, S. J., D. J. Wylie and A. L. Dick. 1997. Methanesulphonate and non-sea-salt sulphate in aerosol, snow and ice on the East Antarctic Plateau. Antarct. Sci., 9(1), 46-55.

Legrand, M. 1995. Sulphur-derived species in polar ice: a review. In Delmas, R. J., ed. Ice core studies of global biogeochemical cycles. Berlin, etc., Springer- 
Verlag, 91-119. (NATO ASI Series I: Global Environmental Change 30.) Legrand, M. R. and R. J. Delmas. 1987. A 220-year continuous record of volcanic $\mathrm{H}_{2} \mathrm{SO}_{4}$ in the Antarctic ice sheet. Nature, 327 (6124), 671-676.

Legrand, M., C. Feniet-Saigne, E. S. Saltzman, C. Germain, N. I. Barkov and V. N. Petrov. 1991. Ice-core record of oceanic emissions of dimethylsulphide during the last climate cycle. Nature, 350(6314), 144-146.

Maupetit, F. and R. J. Delmas. 1992. Chemical composition of falling snow at Dumont d'Urville, Antarctica. F. Atmos. Chem., 14(1), 31-42.

Piccardi, G., R. Udisti and F. Casella. 1994. Seasonal trends and chemical composition of snow at Terra Nova Bay (Antarctica). Int. F. Environ. Anal. Chem., 55, 219-234.

Piccardi, G., E. Barbolani, S. Becagli, R. Traversi and R. Udisti. 1995. Ruolo della stagionalità e dellaltitudine su fenomeni di frazionamento atmosferico e sulla identificazione di fonti secondarie nelle precipitazioni nevose in Antartide. In Csecon, P., ed. Progetto Nazionale di Ricerche in Antartide, IV Convegno Nazionale Contaminazione Ambientale, 6-7 December 1995, Venezia, Italy. Proceedings. Venezia, Università di Venezia, 53-62.

Piccardi, G., S. Becagli, R. Traversi and R. Udisti. 1996a. Fractionating phenomena, altitude induced, on snow composition in northern Victoria Land (Antarctica). In Colacino, M., G. Giovannelli and L. Stefanutti, eds Conference on Italian Research on Antarctic Atmosphere, 6-8 November 1995, Florence, Italy. Proceedings. Vol. 51. Bologna, Società Italiana di Fisica, 229-245.

Piccardi, G., F. Casella and R. Udisti. 1996b. Non-sea-salt contribution of some chemical species to the snow composition at Terra Nova Bay (Antarctica). Int. 7. Environ. Anal. Chem., 63, 207-223.

Prospero, J. M., D. L. Savoie, E. S. Saltzman and R. Larson. 1991. Impact of oceanic sources of biogenic sulphur on sulphate aerosol concentrations at Mawson, Antarctica. Nature, 350(6315), 221-223.

Saltzman, E. S. 1995. Ocean/atmosphere cycling of dimethylsulfide. In Delmas,
R. J., ed. Ice core studies of global biogeochemical cycles. Berlin, etc., SpringerVerlag, 65-90. (NATO ASI Series I: Global Environmental Change 30.)

Savoie, D. L. and J. M. Prospero. 1989. Comparison of oceanic and continental sources of non-sea-salt over the Pacific Ocean. Nature, 339(6227), 685-687.

Shaw, G. E. 1988. Antarctic aerosols: a review. Rev. Geophys., 26(1), 89-112.

Tuncel, G., N. K. Aras and W. H. Zoller. 1989. Temporal variations and sources of elements in the South Pole atmosphere. 1. Nonenriched and moderately enriched elements. F. Geophys. Res., 94(D10), 13,025-13,038.

Udisti, R. 1996. Multiparametric approach for chemical dating of snow layers from Antarctica. Int. F. Environ. Anal. Chem., 63, 225-244.

Udisti, R., E. Barbolani and G. Piccardi. 1991. Determination of some organic and inorganic substances present at ppb level in Antarctic snow and ice by ion chromatography. Ann. Chim., 81(7-8), 325-341.

Udisti, R., F. Casella and G. Piccardi. 1993. The role of methanesulphonic acid in snow samples from Terra Nova Bay (Antarctica). In Restelli, G. and G. Angeletti, eds. Dimethylsulphide: oceans, atmosphere and climate (1992). Dordrecht, etc., Kluwer Academic Publishers, 153-162. (Air Pollution Research Report 43.)

Udisti, R., S. Bellandi and G. Piccardi. 1994. Analysis of snow from Antarctica: a critical approach to ion-chromatographic methods. Fresenius' f. Anal. Chem., 349(4), 289-293.

Udisti, R., R. Traversi, S. Becagli and G. Piccardi. 1998. Spatial distribution and seasonal pattern of biogenic sulphur compounds in snow from northern Victoria Land, Antarctica. Ann. Glaciol., 27, 535-542.

Wagenbach, D. 1996. Coastal Antarctica: atmospheric chemical composition and atmospheric transport. In Wolff, E.W. and R.C. Bales, eds. Chemical exchange between the atmosphere and polar snow. Berlin, etc., Springer-Verlag, 173-199. (NATO ASI Series I: Global Environmental Change 43.) 